\title{
A mathematical model for the development of mealiness in apples
}

\author{
V. De Smedt a, P. Barreiro ${ }^{\text {b }}$, B.E. Verlinden ${ }^{\text {a, }}$, E.A. Veraverbeke ${ }^{\text {a }}$, \\ J. De Baerdemaeker ${ }^{a}$, B.M. Nicolaï ${ }^{\mathrm{a}, *}$ \\ ${ }^{a}$ Flanders Centre/Laboratory of Postharvest Technology, Catholic University of Leuven, Willem de Croylaan 42, \\ 3001 Leuven, Belgium

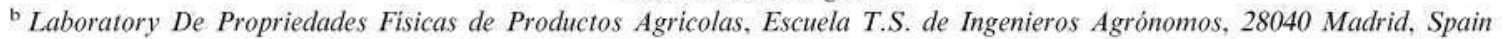

Received 27 April 2001; accepted 16 October 2001

\begin{abstract}
Mealiness in apples (Malus domestica Borkh.) is an internal quality defect which is characterised by a dry and crumbly texture. It is related to the relative strength of the cell wall and the middle lamella. A mathematical model has been built to relate changes in the texture attributes juiciness, tensile strength and hardness, which are associated with mealiness, to the development of the turgor pressure of the tissue and the degree of hydrolysis of the middle lamella. The latter, in turn, are described in terms of properties which are meaningful from the physiological point of view, such as starch content, soluble solids content, non-hydrolysed and hydrolysed middle lamella, water in the symplast, and water in the apoplast. Biochemical reactions as well as water transfer processes are incorporated in the model. The parameter values of the model are estimated using experimental data from a storage experiment. The model fits the three texture characteristics adequately. The correlation coefficients between the parameters were below 0.96 , which indicates that the model does not overfit the data.
\end{abstract}

Keywords: Apple; Mathematical model; Mealiness; Middle lamella

\section{Introduction}

Mealiness is an important internal quality parameter of apple, which is characterised by texture deterioration, resulting in soft, dry and mealy fruit. Mealiness reduces the quality of the fruit, and, hence, its commercial value, and in apple develops during storage and depends on the air composition, temperature and relative humidity. It can be induced by applying room temperature $\left(20{ }^{\circ} \mathrm{C}\right)$ and high relative humidity $(95 \%$; Barreiro et al., 1998b). Apples stored in refrigerated but normal air conditions develop a mealy texture much faster than apples under ultra low oxygen (ULO) conditions (De Smedt, 2000). Apart from the storage conditions, harvesting date and fruit size also influence the development of mealiness. Apples of larger size or of late 
harvest are more susceptible to mealiness (Barreiro et al,, 2000; De Smedt, 2000).

Hatfield and Knee (1988) and De Smedt et al. (1998) concluded that the cells in mealy apples become more rounded, and, as a consequence, the amount of apoplast is larger in mealy apples than in fresh apples. Mealiness in apple is related to the relative strength of the cell wall compared with the strength of the middle lamella (Harker and Hallett, 1992; De Smedt et al., 1998).

Sensory analysis has shown that mealiness can be characterised by a combination of a lack of crispiness, a lack of juiciness and a lack of hardness (Barreiro et al., 1998b). Crispiness appears to be a characteristic which is lost soon after harvest, whereas hardness and juiciness decrease more gradually during storage. Barreiro et al. (1998a) were able to relate these three sensory characteristics to three instrumentally measured parameters. Hardness was measured as the slope of the force deformation curve in a confined compression test. Juiciness was determined by placing a small filter paper under the apple sample during compression and measuring the size of the wet spot immediately after compression. Crispiness was measured by performing a shear-rupture or tensile test. The maximum force reached on the force deformation curve was used as a measure for crispiness.

Although qualitative information is available with respect to the development of mealiness in apples as a function of the storage conditions, to date no model is available for quantitative prediction purposes. Such a model would be useful for optimising storage conditions with respect to the development of mealiness. The objective of this work was, therefore, to build a mechanistic model which describes the changes of the middle lamella, the water transfer through the tissue and their interaction at the cellular level as affected by the relative humidity for both air and low oxygen storage. The model explains the development of the hardness, tensile strength and juiciness of apple tissue. These mechanical parameters have been shown to be directly related to mealiness as perceived by sensory panels (Barreiro et al., 1998b).

\section{Kinetic model development}

\subsection{Model framework}

Texture properties of apple such as mealiness are affected by the mechanical properties of the cell walls and middle lamellae, by the water status and, in particular, turgor pressure of the cell (Pitt, 1982). These properties change considerably during postharvest storage and affect each other. For example, a key transformation in apple is the hydrolysis of pectin which requires water as a substrate. Water is available from inside the cells and is also produced through respiration. It was, therefore, decided to include the following general features in the model,

- respiration;

- changes of the middle lamella;

- transfer of water in the apple;

- relations between fruit texture attributes and the middle lamella and cell turgor.

For the purpose of this article it was assumed that the apple can be considered as a homogeneous object. The only independent variable left is time and, therefore, ordinary differential equations are sufficient to define the model structure. It is noted that the model which is derived below should, therefore, be considered as a crude approximation of the reality.

The model is based on a simplification of the histological structure of the apple (Fig. 1). It is assumed that the apple consists of two compartments, the symplast, consisting of the entire network of cytoplasm interconnected by plasmodesmata, and the apoplast, consisting of the cell wall system and the intercellular space (Taiz and Zeiger, 1998). The symplast is separated from the apoplast by a semi-permeable mem-

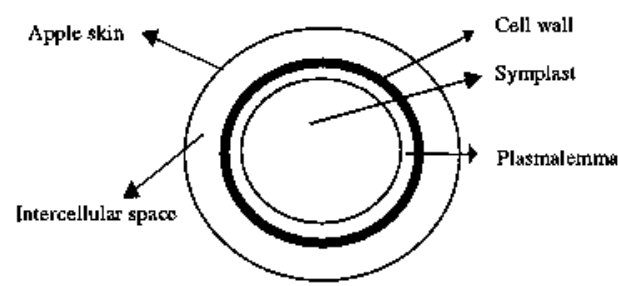

Fig. 1. Schematic representation of an apple. 
brane, the plasmalemma. Passive (diffusive) transport of water between both compartments is possible through the plasmalemma. The apoplast can exchange water with the environment via epidermal transfer. The apple skin, with its protective wax layer, is the major barrier for this transfer. The water loss of 'Cox's Orange Pippin' apples during a commercial storage period of 6 months at $3{ }^{\circ} \mathrm{C}$ and $90 \% \mathrm{RH}$ is typically $5 \%$ or greater.

Relative humidity can be considered as a property of the environment, which affects the behaviour of the apple. It is an input variable of the model and is available to the postharvest technologist to optimise the storage process. The effect of the ripeness stage of the apple on the relevant enzyme-mediated biochemical reactions was not considered in this paper, as only one batch of fruit was used. Further, the temperature was assumed to be at its optimal value and its effect was not modelled explicitly as no data were available for different storage temperatures. Finally, experimental data were available for two storage conditions (controlled atmosphere (CA) and normal air), and the air composition was considered as a categorical variable. As a consequence, the oxygen concentration does not enter into the model equations as such. The apple skin was chosen as the system boundary.

\subsection{Modelled processes}

Respiration provides a source of symplastic water and, therefore, needs to be incorporated in the model. In the symplast the respiration process is governed by two overall chemical reactions. One describes the hydrolysis of starch to hexose sugars and the other describes the oxidation of hexose sugars to provide energy. After harvest, apples still contain a certain amount of starch depending on the ripeness stage at harvest. During storage the starch is hydrolysed resulting in an accumulation of sugar (Kays, 1991). To model this phenomenon, a hypothetical dissolution site is assumed for representing positions in the starch polymers where hydrolysis occurs. The dissolution sites (S) are dissolved in the symplastic water. Whenever, a dissolution site is hydrolysed, a hexose unit $(\mathbf{H})$ is produced.
$\mathrm{S}+\mathrm{H}_{2} \mathrm{O} \stackrel{k_{S}}{\rightarrow} \mathrm{H}$

During storage, hexose units are converted by means of molecular oxygen into carbon dioxide and water. As fermentation during commercial storage is avoided at all costs, it is assumed that the conversion is governed by aerobic respiration only.

$\mathrm{H}+6 \mathrm{O}_{2} \stackrel{k_{\mathrm{H}}}{\rightarrow} 6 \mathrm{CO}_{2}+6 \mathrm{H}_{2} \mathrm{O}$

Carbon dioxide diffuses through the apple to the environment.

The hydrolysis of the middle lamella in the apoplast was considered as well, as this phenomenon affects the overall texture to a large extent. During ripening and softening, the middle lamella, which consists mainly of pectins, dissolves. The basic structure of pectic substances consists of chains of galacturonic acid residues linked by $\alpha(1 \rightarrow 4)$ glycosidic bonds. A wide range of side chains can be found attached to the main chain residues. Pectic substances can undergo a variety of chemical modifications. These are reactions catalysed by different enzymes. Enzymes capable of catalysing the de-methoxylation and de-polymerisation of pectic materials are widespread in fruit and vegetables. The concentration of many hydrolases, including polygalacturonases, increases with maturity (Van Buren, 1979; BenArie and Kislev, 1979; Fisher and Bennet, 1991).

To simplify the model, a simple hydrolysis reaction is assumed in which galacturonic acid units are subsequently detached from the pectin chain. Similar to the conversion of starch, a hypothetical dissolution site was assumed to represent $\alpha(1 \rightarrow 4)$ glycosidic bonds on the middle lamella were hydrolysis occurs. The dissolution sites (L) are assumed to be dissolved in the intercellular water but are physically attached to the pectin matrix which is not in solution. Whenever a dissolution site is hydrolysed, a pectin monomer $(\mathrm{P})$ is produced.

$\mathrm{L}+\mathrm{H}_{2} \mathrm{O} \stackrel{k_{\mathrm{L}}}{\rightarrow} \mathrm{P}$

For this reaction, water is required. The rate is assumed to depend on the concentration of middle lamella dissolution sites and the amount of water inside the apoplast. 


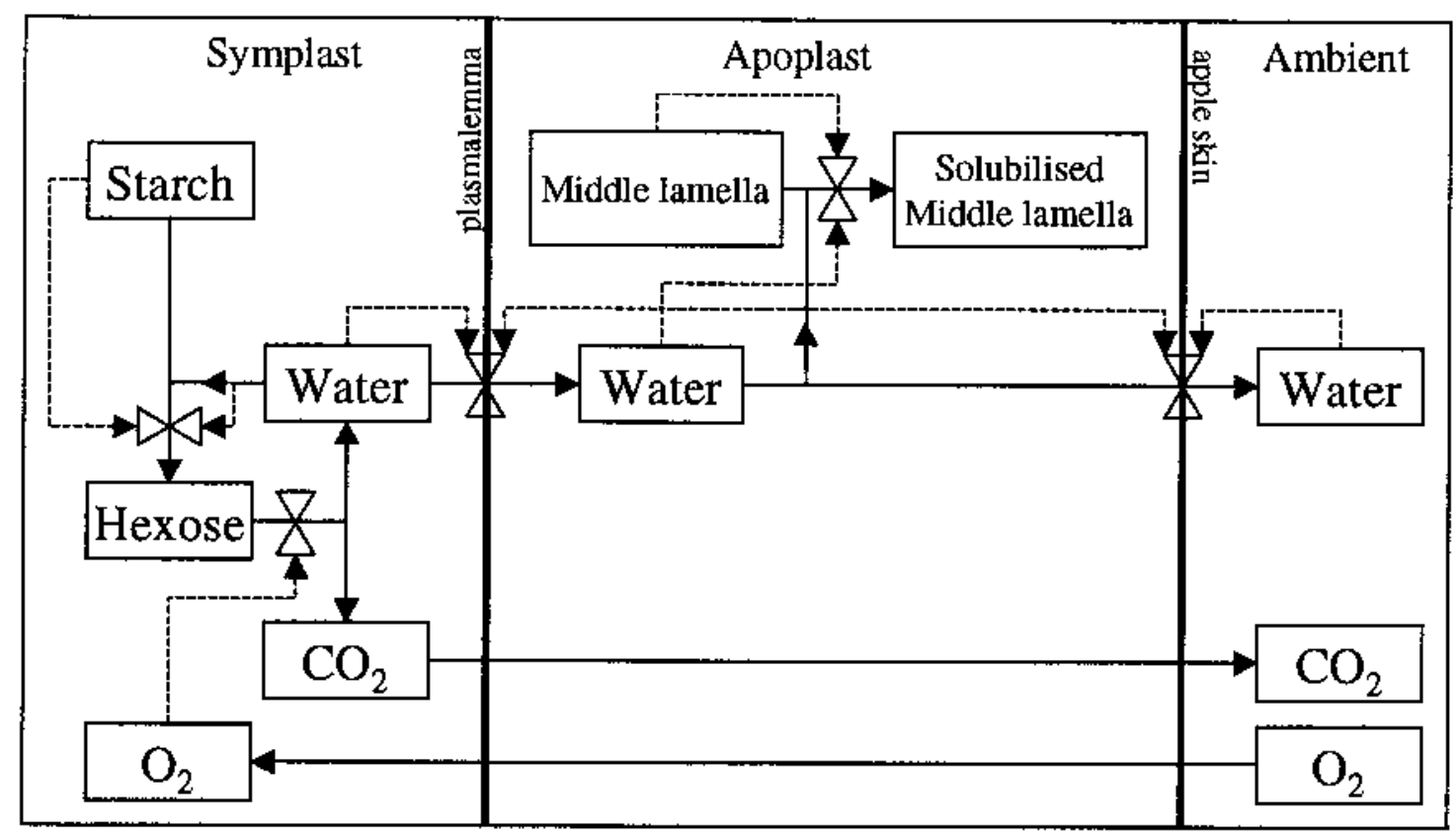

Fig. 2. Schematic representation of the model, Full arrows denote mass streams while dashed arrows denote influences of conversion or flow rates denoted by two connected triangles.

Besides these chemical processes, the water exchange processes between the compartments and the environment are modelled. Gas exchange is not incorporated and gas gradients between the compartments and the environment are considered to be zero. How the above processes relate to each other is schematically presented in Fig. 2.

It is assumed that the symplast contains water $\left(W_{s}\right)$ and sugar substrate in the form of starch dissolution sites (S) and hexose units $(\mathrm{H})$. The apoplast contains middle lamella dissolution sites (L), solubilised middle lamella (P) and also some water $\left(W_{\mathrm{a}}\right)$. The amount of molecules or ions in solution other than substrate and water (e.g. K ', $\mathrm{Cl}^{-}$) are not considered. Part of the water inside the cell is transferred to the apoplast. This transfer is driven by a difference in water potential between the two compartments. Finally, part of the water is lost to ambient. The transfer rate depends on the relative humidity of the ambient. The concentration of these six chemical compounds, $\mathrm{S}, \mathrm{H}, \mathrm{L}, \mathrm{P}, \mathrm{W}_{\mathrm{s}}$ and $\mathrm{W}_{\mathrm{a}}$ are defined as the state variables of the model.

\subsection{Model structure}

The mathematical structure of the model will now be developed in different steps based on the chemical kinetics of the selected processes and water transfer phenomena by specifying mass balances in terms of differential equations. This will result in the core structure of the model which describes the state of the system and how the system state changes depending on environmental conditions. In a last step a relation between the state of the apple (system) and measurable mechanical properties related to mealiness will be established. Note that the rate of enzyme-mediated reactions is always assumed to be independent of the availability or activity of the involved enzymes, as data of only one batch of fruit have been considered in this article. This assumption may not be valid when batches from different harvest and maturity levels would be considered.

How the state of the apple changes over time is modelled by setting up a mass balance for each of the six chemical compounds ( $\mathrm{S}, \mathrm{H}, \mathrm{L}, \mathrm{P}, \mathrm{W}_{\mathrm{s}}, \mathrm{W}_{\mathrm{a}}$ ). This results in a first order differential equation 
for each state variable. The accumulation of a compound in the system is the result of four terms: inflow and outflow through the system boundaries and production and consumption inside the system. First, the flow and conversion terms will be defined and then they will be used to develop the mass balances which will result in a system of differential equations.

The rate of the hydrolysis of starch, $v_{S}$, is defined as the conversion of the amount of substrate (S) per mole reaction medium and per second. Further, it is assumed that this rate is proportional to both the activity of dissolution sites and water in the symplast. For simplicity it is assumed that the activity of a chemical component is approximately equal to its concentration.

$v_{S}=k_{\mathrm{S}}[\mathrm{S}]\left[\mathrm{W}_{\mathrm{s}}\right]$

The rate of oxidation of sugars, $v_{\mathrm{H}}$, is defined as the conversion of the amount of hexose substrate, $\mathbf{H}$, per mole reaction medium and per second. This rate depends on the physiological state and temperature. As the oxygen concentration is believed to be constant in controlled air conditions and hexose is in practice not a limiting substrate during a normal storage period, zero-order kinetics is assumed:

$v_{\mathrm{H}}=k_{\mathrm{H}}$

Note that the oxygen dependency is absorbed in the rate constant $k_{\mathrm{H}}$ and is different for CA and normal air conditions.

The rate of the hydrolysis of the middle lamella, $v_{\mathrm{L}}$, is defined as the conversion of the amount of substrate, $\mathrm{L}$, per unit amount of reaction medium and per second. The rate is assumed to be proportional to both the concentration of dissolution sites and water in the apoplast.

$v_{\mathrm{L}}=k_{\mathrm{L}}[\mathrm{L}]\left[\mathrm{W}_{\mathrm{a}}\right]$

During commercial storage, apples lose a certain amount of water depending on several factors such as variety, ripeness stage, fruit size, storage temperature and relative humidity in the cool chambers. Water is lost to the apoplast when the water potential inside the symplast is higher than in the apoplast. Water is consumed in the hydrolysis of starch and produced in the respiration reaction. According to Nobel (1991), the water potential $(\Psi)$ is defined as:

$\Psi=\Psi_{\mathrm{p}}+\Psi_{\text {त }}$

with $\Psi_{\mathrm{p}}(\mathrm{Pa})$ the hydrostatic potential or turgor pressure potential, and $\Psi_{\pi}(\mathrm{Pa})$ the osmotic potential. It is assumed that the matric potential is zero. If the water potential $\left(\Psi_{1}\right)$ of compartment 1 is different from the water potential $\Psi_{2}$ of compartment 2, and if both are separated by means of a semi-permeable membrane, then water will be transferred from the compartment of the highest potential to that with the lowest potential. According to Fick's first law, the flux of water from compartment 1 to compartment 2 is proportional to the difference in water potential. The transfer of water from the symplast to the apoplast is driven by the water potential difference according to:

$r_{\mathrm{w}_{\mathrm{s}}}=h_{\mathrm{s}} A_{\mathrm{s}}^{*}\left(\Psi_{\mathrm{s}}-\Psi_{\mathrm{a}}\right)$

with $r_{\mathrm{W}_{s}}$ the transfer rate of water from the symplast to the apoplast, $h_{\mathrm{s}}$ a mass transfer coefficient for water from the symplast to the apoplast, $A_{s}^{*}$, the total cell membrane area in the symplast and $\Psi_{\mathrm{s}}$ and $\Psi_{\mathrm{a}}$, respectively, the total water potential of the water in the symplast and apoplast.

The symplastic osmotic potential $\Psi_{\pi, s}$ depends on the water activity according the following equation (Nobel, 1991).

$\Psi_{\pi, \mathrm{s}}=\frac{R T}{\bar{V}_{\mathrm{W}}} \ln a_{\mathrm{W}_{\mathrm{s}}}$

with $a_{W_{s}}$ the water activity in the cell, $R$ the gas constant $(8.314 \mathrm{~J} / \mathrm{mol} \mathrm{K}), T$ the absolute temperature $(\mathrm{K})$ and $\bar{V}_{\mathrm{W}}$ the partial molar volume of water $\left(18 \times 10^{-6} \mathrm{~m}^{3} / \mathrm{mol}\right)$. For sugar solutions and high moisture food products $\left(a_{\mathrm{w}}>0.75\right), a_{\mathrm{w}}$ can be related to the concentration of the solvent expressed as a mole fraction (Nobel, 1991):

$a_{\mathrm{W}_{\mathrm{s}}}=\delta\left[\mathrm{W}_{\mathrm{s}}\right]$

with $\delta$ the activity coefficient. For dilute solutions (less then 0.1 mole/ $/$ of solvent, Taiz and Zeiger, 1998 ) the activity coefficient is close to 1 . Although in the case of apples there is more than 0.1 mole of sugar per litre of solvent, the activity coefficient is assumed to be 1 . Hence, the osmotic potential in the symplast is given by: 


$$
\Psi_{\pi, \mathrm{s}}=\frac{R T}{\bar{V}_{\mathrm{W}}} \ln \left[\mathrm{W}_{\mathrm{s}}\right]
$$

From Eq. (7), it is clear that the turgor potential is given by:

$$
\Psi_{p, s}=\Psi_{s}-\Psi_{\pi, s}
$$

The osmotic potential in the symplast, $\Psi_{\pi, s}$, is given by $\mathrm{Eq}$. (11) and the total water potential, $\Psi_{s}$, is assumed to be linearly dependent on the water content of the tissue:

$\Psi_{\mathrm{s}}=a\left(W_{\mathrm{s}}+W_{\mathrm{a}}\right) M_{\mathrm{W}}-b$

where, $\left(W_{\mathrm{s}}+W_{\mathrm{a}}\right) M_{\mathrm{W}}$ is the water content of the tissue expressed as a proportion of the fresh weight. As the turgor pressure cannot be negative, the following relations can be established:

$\Psi_{\mathrm{D}, \mathrm{s}}=0, \quad \Psi_{\pi, \mathrm{s}}>\Psi_{\mathrm{s}}$

$\Psi_{\mathrm{p}, \mathrm{s}}=\Psi_{s}-\Psi_{\pi, s}, \quad$ otherwise

The osmotic active species in the apoplast are galacturonic acid monomers. The osmotic potential in the apoplast is given by:

$\Psi_{\pi, \mathrm{a}}=\frac{R T}{\bar{V}_{\mathrm{W}}} \ln a_{\mathrm{W}_{\mathrm{a}}}=\frac{R T}{\bar{V}_{\mathrm{W}}} \ln \left[\mathrm{W}_{\mathrm{a}}\right]$

The turgor potential of the apoplast is, by definition, equal to zero.

Water is also transferred from the apoplast to ambient with a rate depending on the relative humidity of the environment. The lower the relative humidity, the more water is lost to ambient. There is also inflow of water to the apoplast from the symplast. The transfer rate of water from the apoplast to ambient is, in analogy to, $r_{\mathrm{w}}$, proportional to the difference in water potential:

$r_{\mathrm{W}_{\mathrm{a}}}=h_{\mathrm{a}} A_{\mathrm{a}}^{*}\left(\Psi_{\mathrm{a}}-\Psi_{-\infty}\right)$

with $\Psi_{-\infty}$ the water potential of ambient surrounding the apple, $h_{a}$ a mass transfer coefficient from the apoplast to ambient, and $A_{\mathrm{a}}^{*}$ the total apple surface area. $\Psi_{\infty}$ can be rewritten:

$\Psi_{\infty}=\frac{R T}{\overline{V_{\mathrm{w}}}} \ln \left(\phi_{\mathrm{rel}}\right)$

with $\phi_{\text {rel }}$ the relative humidity of the environment surrounding the apple.
All conversion and flow rates are defined and will now be used to develop the mass balances of the six chemical compounds resulting in a system of differential equations. The change of starch dissolution sites, $S$, in time is proportional to the hydrolysis rate of starch, $v_{\mathrm{S}}$, and the amount of molecules, $\left(n_{\mathrm{S}}+n_{\mathrm{H}}+n_{\mathrm{w}_{S}}\right)$, in the symplast.

$\frac{\mathrm{d} n_{\mathrm{S}}}{\mathrm{dt}}=-v_{\mathrm{S}}\left(n_{\mathrm{S}}+n_{\mathrm{H}}+n_{\mathrm{w}_{\mathrm{s}}}\right) \quad$ with $\quad n_{\mathrm{S}}(t=0)=n_{\mathrm{S}_{0}}$

The amount of hexose in the symplast compartment increases because it is produced from starch and it decreases because of respiration:

$$
\begin{gathered}
\frac{\mathrm{d} n_{\mathrm{H}}}{\mathrm{dt}}=\left(v_{\mathrm{S}}-v_{\mathrm{H}}\right)\left(n_{\mathrm{S}}+n_{\mathrm{H}}+n_{\mathrm{w}_{\mathrm{s}}}\right) \quad \text { with } \\
n_{\mathrm{H}}(t=0)=n_{\mathrm{H}_{0}}
\end{gathered}
$$

An analogous derivation for the change of pectin substrate and pectin monomers can be made which results in:

$$
\begin{aligned}
& \frac{\mathrm{d} n_{\mathrm{L}}}{\mathrm{dt}}=-v_{\mathrm{L}}\left(n_{\mathrm{L}}+n_{\mathrm{P}}+n_{\mathrm{w}_{\mathrm{a}}}\right), \quad \text { with } \\
& \quad n_{\mathrm{L}}(t=0)=n_{\mathrm{L}_{0}} \\
& \frac{\mathrm{d} n_{\mathrm{P}}}{\mathrm{dt}}=v_{\mathrm{P}}\left(n_{\mathrm{L}}+n_{\mathrm{P}}+n_{\mathrm{w}_{\mathrm{a}}}\right), \quad \text { with } \quad n_{\mathrm{P}}(t=0)=n_{\mathrm{P}_{0}}
\end{aligned}
$$

The water balance in the symplast has three terms, water produced during respiration of sugars; water consumption in the hydrolysis reaction of starch; and water loss through the plasmalemma.

$$
\begin{gathered}
\frac{\mathrm{d} n_{\mathrm{W}_{\mathrm{s}}}}{\mathrm{dt}}=\left(6 v_{\mathrm{H}}-v_{\mathrm{S}}\right)\left(n_{\mathrm{S}}+n_{\mathrm{H}}+n_{\mathrm{W}_{\mathrm{s}}}\right)-r_{\mathrm{W}_{\mathrm{s}}}, \quad \text { with } \\
n_{\mathrm{W}_{\mathrm{s}}}(t=0)=n_{\mathrm{W}_{\mathrm{s} 0}}
\end{gathered}
$$

The water balance in the apoplast has three terms as well, water consumption in the hydrolysis reaction of pectin in the middle lamellae, water inflow from the symplast and water loss to ambient.

$$
\begin{aligned}
& \frac{\mathrm{d} n_{\mathrm{W}_{\mathrm{a}}}}{\mathrm{dt}}=-v_{\mathrm{L}}\left(n_{\mathrm{L}}+n_{\mathrm{P}}+n_{\mathrm{W}_{\mathrm{a}}}\right)+r_{\mathrm{W}_{\mathrm{s}}}-r_{\mathrm{W}_{\mathrm{a}}}, \quad \text { with } \\
& n_{\mathrm{W}_{\mathrm{a}}}(t=0)=n_{\mathrm{W}_{\mathrm{a} 0}}
\end{aligned}
$$


These six differential equations can be rewritten as follows.

In $\mathrm{Eq}$. (4), the concentration of the dissolution sites $\mathrm{S}$ is defined as the molar fraction:

$[\mathrm{S}]=\frac{n_{\mathrm{S}}}{n_{\mathrm{S}}+n_{\mathrm{H}}+n_{\mathrm{w}_{\mathrm{s}}}}$

The concentrations of intracellular water and hexose units are defined in a similar way. Eq. (18) can then be written as:

$\frac{\mathrm{d} n_{\mathrm{S}}}{\mathrm{dt}}=-k_{\mathrm{S}} n_{\mathrm{S}} \frac{n_{\mathrm{W}_{\mathrm{s}}}}{n_{\mathrm{S}}+n_{\mathrm{H}}+n_{\mathrm{w}_{\mathrm{s}}}}$

This equation holds for a certain apple with a certain fresh weight. The fresh weight, $m_{\text {apple, } 0}$, is defined as the weight immediately after harvest. It is advantageous to introduce the following concentrations expressed in mols per $\mathrm{kg}$ fresh weight:

$S=\frac{n_{\mathrm{S}}}{m_{\text {apple }, 0}}, \quad H=\frac{n_{\mathrm{H}}}{m_{\text {apple }, 0}}, \quad W_{s}=\frac{n_{\mathrm{W}_{\mathrm{s}}}}{m_{\text {apple }, 0}}$

Substitution into $\mathrm{Eq}$. (25) yields:

$\frac{\mathrm{d} S}{\mathrm{~d} t}=-k_{\mathrm{S}} S \frac{W_{\mathrm{s}}}{S+H+W_{\mathrm{s}}}, \quad$ with $\quad S(t=0)=S_{0}$

In a similar manner these substitutions were carried out for the other five differential equations resulting in:

$$
\begin{aligned}
& \frac{\mathrm{d} H}{\mathrm{~d} t}=-k_{\mathrm{H}}\left(S+H+W_{\mathrm{s}}\right)+k_{\mathrm{S}} S \frac{W_{\mathrm{s}}}{S+H+W_{\mathrm{s}}}, \\
& \text { with } \quad H(t=0)=H_{0}
\end{aligned}
$$

$\frac{\mathrm{d} L}{\mathrm{~d} t}=-k_{\mathrm{L}} L \frac{W_{\mathrm{a}}}{L_{0}+P_{0}+W_{\mathrm{a}}}, \quad$ with $\quad L(t=0)=L_{0}$

$\frac{\mathrm{d} P}{\mathrm{~d} t}=k_{\mathrm{L}} L \frac{W_{\mathrm{a}}}{L_{0}+P_{0}+W_{\mathrm{a}}}, \quad$ with $\quad P(t=0)=P_{0}$

$$
\begin{aligned}
\frac{\mathrm{d} W_{\mathrm{s}}}{\mathrm{d} t}= & 6 k_{\mathrm{H}}\left(S+H+W_{\mathrm{s}}\right)-k_{\mathrm{S}} S \frac{W_{\mathrm{s}}}{S+H+W_{\mathrm{s}}} \\
& -h_{\mathrm{s}} A_{\mathrm{s}}\left(\Psi_{\mathrm{s}}-\Psi_{\mathrm{a}}\right), \quad W_{\mathrm{s}}(t=0)=W_{\mathrm{s}, 0}
\end{aligned}
$$

$\frac{\mathrm{d} W_{\mathrm{a}}}{\mathrm{d} t}=h_{\mathrm{s}} A_{\mathrm{s}}\left(\Psi_{\mathrm{s}}-\Psi_{\mathrm{a}}\right)-h_{\mathrm{a}} A_{\mathrm{a}}\left(\Psi_{\mathrm{a}}-\Psi_{\mathrm{s}}\right)$

$$
\begin{gathered}
-k_{\mathrm{L}} L \frac{W_{\mathrm{a}}}{L_{0}+P_{0}+W_{\mathrm{a}}} \quad \text { with } \\
W_{\mathrm{a}}(t=0)=W_{a, 0}
\end{gathered}
$$

Besides storage conditions, mealiness is also affected by other parameters such as harvest time and fruit size. Larger apples and later picked apples are more susceptible to the development of a mealy texture. Since those parameters influence the system but can not be influenced by the system themselves, they are considered to be inputs of the system. The initial values of the symplast properties are a function of harvest time and fruit size. For example, late harvested apples have a higher amount of soluble solids and a lower amount of starch than early harvested apples.

\subsection{Output relations}

In this third step, the relations between the state of the apple and measurable mechanical properties are proposed. The desired outputs of the model are tensile strength $[N]$, compressive hardness $(\mathrm{N} / \mathrm{mm})$ and juiciness $\left(\mathrm{mm}^{2}\right)$. Apart from those, soluble solids content and weight loss are also considered as output variables.

When a load is applied to apple tissue with a strong middle lamella, the cell walls break preferentially, liberating juice and thereby giving a sensation of crispiness and juiciness. In contrast, when the middle lamella is dissolved and weak, the tissue will yield along the middle lamella. The proportion of broken cells (broken cell index, $B$ ) can, therefore, be considered as the amount of undissolved middle lamella relative to the total amount of middle lamella (dissolved + undissolved).

$$
B=\frac{L}{L_{0}+P_{0}}
$$

Juiciness is modelled starting from this broken cell index. The juice released during the confined compression test is partly originating from inside the cells when they break and partly from the water in the apoplast.

$J=c\left(W_{\mathrm{a}}+B W_{\mathrm{s}}\right)$

with $J$ juiciness measured as the spot on a filter paper.

When the middle lamellae of the apples are still strong, the cell walls will break when a tensile force 
is applied to the apple tissue. If the middle lamellae is weak, then the cells will tear apart along their middle lamellae. The tensile strength can, therefore, be described by the following relationship:

$F_{\max }^{\mathrm{t}}=B F_{\max , \text { wall }}^{\mathrm{t}}+(1-B) F_{\max , \mathrm{L}}^{\mathrm{t}}$

with $F_{\max }^{\mathrm{t}}$ the tensile strength of the tissue measured as the maximum force in a tensile test, and $F_{\max }^{\mathrm{t}}$, wall and $F_{\max , \mathrm{L}}^{\mathrm{t}}$ the tensile strength of the cell walls and middle lamellae, respectively. Unlike compressive strength, the tensile strength of the cell wall increases with increasing potential, and hence with increasing turgor potential (De Baerdemaeker et al., 1978). A linear relationship between cell wall strength and turgor has been assumed here:

$F_{\max , \text { wall }}^{\mathrm{t}}=d+e \Psi_{\mathrm{p}, \mathrm{s}}^{\mathrm{s}}$

Although in mealy tissue the tensile strength of the middle lamella may somewhat increase with increasing turgor potential because the contact surface area between neighbouring cells may increase slightly, it is assumed here that this effect is of minor importance and $F_{\max , \mathrm{L}}^{\mathrm{t}}$ is considered to be a constant parameter.

Compressive hardness $(\mathrm{N} / \mathrm{mm})$ is related to the elasticity modulus $\left(E,\left(\mathrm{~N} / \mathrm{m}^{2}\right)\right)$. A generalisation of the cell model of Nilsson et al. (1958) is proposed for relating the cell $E$-modulus to the turgor pressure and the amount of middle lamella dissolution sites.

$E=E_{0}+f \Psi_{\mathrm{p}, \mathrm{s}}+g L$

The relation between the $E$-modulus ( $\mathrm{Pa}$ ) of a simple uniaxial compression and the compressive hardness $(\mathrm{N} / \mathrm{mm})$ is given below (De Baerdemaeker and Segerlind, 1976):

$S_{\mathrm{cc}}=\frac{A_{\mathrm{p}}}{l_{\mathrm{p}}} \frac{1-v}{(1+v)(1-2 v)} E$

where $S_{\mathrm{cc}}$ is the hardness measured as the slope of the force-deformation curve in a confined compression test, $A_{\mathrm{p}}\left(2.27 \times 10^{-4} \mathrm{~m}^{2}\right)$ is the cross section of the probe used for the test, $l_{\mathrm{p}}$ is the length of the probe $(17 \mathrm{~mm})$ and $v$ the Poisson's ratio of the material. This can be written as:

$S_{\mathrm{ci}}=\frac{A_{\mathrm{p}}}{l_{\mathrm{p}}} \varepsilon E$ with $\varepsilon=1-v /(1+v)(1-2 v)$. The constant $\varepsilon$ can be incorporated in the parameters $E_{0}, f$ and $g \mathrm{Eq}$. (37) and will be omitted from now on.

The percentage of soluble solids (SSC, $\left({ }^{\circ} \mathrm{Brix}\right)$ ) in the juice is defined as the overall concentration of hexose units and pectin monomers:

$\mathrm{SSC}=\frac{H M_{\mathrm{H}}+P M_{\mathrm{P}}}{\left(W_{\mathrm{s}}+W_{\mathrm{s}}\right) M_{\mathrm{W}}} 100$

with $M_{\mathrm{H}}, M_{\mathrm{P}}$ and $M_{\mathrm{W}}$ the molar mass of hexose, pectin monomer and water, respectively.

The weight loss $(\%)$ was calculated as follows:

$$
\Delta m=\frac{m_{\text {apple, } 0}-m_{\text {apple }}}{n_{\text {apple, } 0}} 100=\left(1-\frac{m_{\text {apple }}}{m_{\text {apple, } 0}}\right) 100
$$

with $m_{\text {apple, o the mass immediately after harvest }}$ and $m_{\text {apple }}$ the mass after a certain period of storage. The proportion of the fresh weight at a certain time was estimated by adding the different compounds of the apple:

$$
\begin{aligned}
\frac{m_{\text {apple }}}{m_{\text {apple, } 0}}= & S M_{\mathrm{S}}+H M_{\mathrm{H}}+L M_{\mathrm{L}}+P M_{\mathrm{P}}+W_{\mathrm{s}} M_{\mathrm{W}} \\
& +W_{\mathrm{a}} M_{\mathrm{W}}+\text { Ash }
\end{aligned}
$$

with $M_{\mathrm{S}}, M_{\mathrm{H}}, M_{\mathrm{L}}, M_{\mathrm{P}}$ and $M_{\mathrm{W}}$ the molar mass of a dissolution site of starch, the molar mass of a hexose molecule, the molar mass of a dissolution site of the middle lamella, the molar mass of a pectin monomer and the molar mass of water, respectively.

The amount of ash (Ash) is considered not to change during storage and calculated from the constraint:

$$
\begin{aligned}
1=\frac{m_{\text {apple, } 0}}{m_{\text {apple }, 0}}= & S_{0} M_{\mathrm{S}}+H_{0} M_{\mathrm{H}}+L_{0} M_{\mathrm{L}}+P_{0} M_{\mathrm{P}} \\
& +W_{\mathrm{s}, 0} M_{\mathrm{W}}+W_{\mathrm{a}, 0} M_{\mathrm{W}}+\text { Ash }
\end{aligned}
$$

\section{Materials and methods}

\subsection{Storage experiment}

The parameter estimation was based on the data from a storage experiment carried out on 'Cox's Orange Pippin' apples. Apples were picked on the commercial harvest date and stored for 6 months under the following conditions, 
- $3{ }^{\circ} \mathrm{C}, 95 \% \mathrm{RH}$, normal air composition;

- $3{ }^{\circ} \mathrm{C}, 95 \% \mathrm{RH}, \mathrm{CA}\left(2 \% \mathrm{O}_{2},<0.7 \% \mathrm{CO}_{2}\right)$.

A total of 100 apples was stored at each condition. Tensile strength was measured as the maximum force in a ring tensile test $\left(F_{\max }^{\mathrm{t}}\right.$ ) performed on a universal testing machine (UTS Testsysteme GmbH, Ulm, Germany; Verlinden and De Baerdemaeker, 1997). Ring-shaped samples with an outer diameter of $17 \mathrm{~mm}$, an inner diameter of $9 \mathrm{~mm}$ and a thickness of $11 \mathrm{~mm}$ were pulled apart by means of two half ring-shaped cylinders over which the ring-shaped sample could slide. The sample was precharged with a force of $1 \mathrm{~N}$ and then stretched with a constant deformation speed of $20 \mathrm{~mm} / \mathrm{min}$ until rupture. Hardness was measured as described by Barreiro et al. (1998a). It was defined as the slope of the force-deformation curve from a confined compression test $\left(S_{\infty}\right)$ carried out on a universal testing machine (UTS Testsysteme GmbH) on cylindrical probes of 17 $\mathrm{mm}$ height and diameter. A maximum deformation of $2.5 \mathrm{~mm}$ was applied at a compression velocity of $20 \mathrm{~mm} / \mathrm{min}$. Deformation was immediately removed at the same velocity. The probes were confined in a disk, which had a hole with the same size as the probes. A filter paper (Albet no. $1305,77.84 \mathrm{~g} / \mathrm{m}^{2}$ ) about the size of the disk was placed beneath it in order to recover the juice extracted during the compression test. The juice content was determined by measuring the area of the spot accumulated in the filter paper after a steady spot size was obtained.

The soluble solids content was measured using a digital refractometer (PR-101, Palette Series, ATAGO CO, Ltd, Japan). Apples were weighed immediately after harvest and after storage. All measurements were done right after harvest and every subsequent 6 weeks.

\subsection{Determination of the EMC curve of apple tissue.}

Measurements of the apple tissue water potential were carried out on three "Cox's Orange Pippin' fruit obtained from a local supermarket. From each fruit, 20 cylinders of $2 \mathrm{~cm}$ height and $1 \mathrm{~cm}$ diameter of apple tissue were recovered and weighed on an analytical balance (Sartorius,
BP160P, Germany) after removing excess moisture with paper. To determine the water potential, the apple tissue cylinders were equally divided and immersed in four solutions with different $a_{\mathrm{w}}$, established by four different mannitol concentrations $(0.2,0.4,0.6$ and $0.8 \mathrm{M})$. After overnight equilibration at $1{ }^{\circ} \mathrm{C}$, the weight of the cylinders, dipped dry on paper, was measured again at regular time intervals, until a stable weight was obtained. The intercept with the $X$-axis of the plot representing the weight difference at equilibrium against the mannitol concentration gives the mannitol concentration for which the apple tissue neither gains or looses weight. The water potential of the apple tissue can then be calculated from the following equation (Nobel, 1991).

$\Psi=\frac{R T}{\bar{V}_{\mathrm{W}}} \ln a_{\mathrm{W}} \cong-R T[\mathrm{M}]$

where $\Psi$ is the water potential of the apple tissue, $a_{w}$ is the water activity of the mannitol solution and $[\mathrm{M}]$ the mannitol concentration $\left(\mathrm{mol} / \mathrm{m}^{3}\right)$ corresponding with this $a_{w}$. The EMC curve was obtained by plotting the water content against the water potential of the apple tissue. The water content was defined as the relative amount of water after drying to constant weight at $105^{\circ} \mathrm{C}$.

\subsection{Parameter estimation}

The model has six state variables, $S, H, L, P$, $W_{s}$ and $W_{\mathrm{a}}$ with six initial conditions, $S_{0}, H_{i}, L_{i}$, $P_{0}, W_{s, 0}$ and $W_{\text {s, } 0}$ and five output variables, $F_{\max }^{\mathrm{t}}$, $S_{\mathrm{cc}}, J, \mathrm{SSC}$ and $\Delta m$.

As a first step, literature data have been used to establish approximate initial values for the state variables. Table 1 indicates the approximate composition of apples as percentage of fresh weight (Belitz and Grosch, 1997). No indication of the approximate amount of starch was given by these authors, while Herrero and Guardia (1992) mentioned $2-3 \%$ of fresh weight as the maximum starch content. As a consequence, the state of the model represents around $97 \%$ of the fresh weight of the apple. Based on this information the initial values for the state variables shown in Table 2 were used in the model calculations. 
Table 1

Approximate compositions of apples (Belitz and Grosch, 1997)

\begin{tabular}{lll}
\hline & $\begin{array}{l}\text { Fresh weight } \\
(\%)\end{array}$ & $\begin{array}{l}\text { Fresh weight } \\
\text { (moles } / \mathrm{kg})\end{array}$ \\
\hline $\begin{array}{l}\text { Total water } \\
\left(W_{5,0}+W_{\mathrm{a}, 0}\right)\end{array}$ & 85 & 47.2 \\
$\begin{array}{l}\text { Total sugars } \\
\left(S_{0}+H_{0}\right)\end{array}$ & 11.1 & \pm 0.6 \\
Titratable acid & 0.6 & \\
Insoluble matter & 2.1 & \\
Pectin & 0.6 & 0.03 \\
Ash & 0.3 & \\
Others & 0.3 & \\
\hline
\end{tabular}

Additional information from the literature was used to calculate values for some of the model constants (listed in Table 2) or to assign realistic starting values to the parameters to be estimated through fitting.

$A_{\text {a }}$ was estimated assuming an apple to be spherical with a radius of $37.5 \mathrm{~mm}$, and an average weight of $170 \mathrm{~g}$, corresponding to a value of $0.10395 \mathrm{~m}^{2} / \mathrm{kg}$ fresh weight.

$A_{\mathrm{s}}$ was estimated based on Reeve (1953) who measured the total surface are of cell wall area per unit volume for different apple varieties.

Table 2

Constants and estimated initial values

\begin{tabular}{|c|c|}
\hline Initial values of state variables & Molecular masses \\
\hline$S_{0}=0.10985 \mathrm{~mol} / \mathrm{kg}$ & $\begin{array}{l}M_{\mathrm{s}}=162 \times 10^{-3} \\
\mathrm{~kg} / \mathrm{mol}\end{array}$ \\
\hline$H_{0}=0.58 \mathrm{~mol} / \mathrm{kg}$ & $\begin{array}{l}M_{11}=180 \times 10^{-3} \\
\mathrm{~kg} / \mathrm{mol}\end{array}$ \\
\hline$L_{0}=0.0257 \mathrm{~mol} / \mathrm{kg}$ & $\begin{array}{l}M_{\mathrm{I}}=176 \times 10^{-3} \\
\mathrm{~kg} / \mathrm{mol}\end{array}$ \\
\hline$P_{0}=0,0040457 \mathrm{~mol} / \mathrm{kg}$ & $\begin{array}{l}M_{\mathrm{P}}=194 \times 10^{-3} \\
\mathrm{~kg} / \mathrm{mol}\end{array}$ \\
\hline$W_{\mathrm{s}, 0}=45 \mathrm{~mol} / \mathrm{kg}$ & $\begin{array}{l}M_{\mathrm{W}}=18 \times 10^{-3} \\
\mathrm{~kg}^{\prime} / \mathrm{mol}\end{array}$ \\
\hline \multicolumn{2}{|c|}{$W_{\mathrm{a}, \mathrm{o}}=3.22 \mathrm{~mol} / \mathrm{kg}$} \\
\hline \multicolumn{2}{|c|}{ Other constants used in the model calculations } \\
\hline $\begin{array}{l}A_{\mathrm{p}}=0.227 \times 10^{-3} \mathrm{~m}^{2} \\
A_{\mathrm{st}}=0.10395 \mathrm{~m}^{2} / \mathrm{kg} \\
A_{\mathrm{s}}=6.45 \mathrm{~m}^{2} / \mathrm{kg} \\
a=45.25 \mathrm{MPa}\end{array}$ & $\begin{array}{l}l_{\mathrm{r}}=0.017 \mathrm{~m} \\
R=8.314 \mathrm{~J} / \mathrm{mol} \mathrm{K} \\
T=276 \mathrm{~K} \\
\bar{V}_{\mathrm{W}}=18 \times 10^{-6} \\
\mathrm{~m}^{3} / \mathrm{mol}\end{array}$ \\
\hline$b=40.724 \mathrm{MPa}$ & $\phi_{\mathrm{ret}]}=0.95$ \\
\hline
\end{tabular}

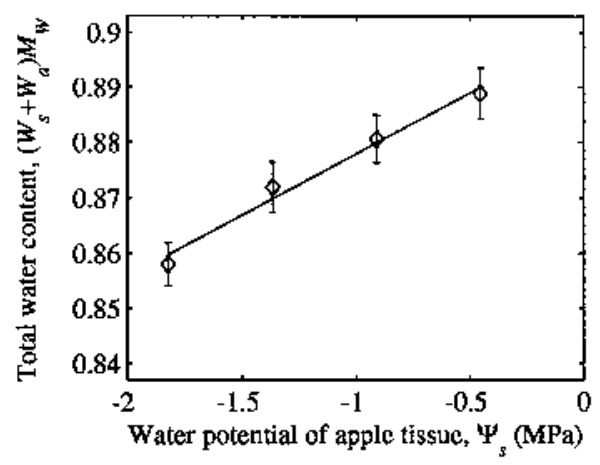

Fig. 3. Water content of apple tissue samples in equilibrium with four mannitol solutions expressed as water potential. Symbols denote mean values of 15 samples. Error bars denote $95 \%$ confidence interval of the means.

The calculated number was $6.45 \mathrm{~m}^{2} / \mathrm{kg}$ fresh weight.

Hertog et al. (1997) modelled the degradation of starch and oxidation of sugars in potatoes. Rate constants for starch and sugar degradation differed from season to season and were between 0.0161 and 0.0033 ( 1 per day) and $8.39 \times 10^{-5}$ and $1.53 \times 10^{-2}$ ( 1 per day) for, respectively, starch and sugar.

The EMC curve of 'Cox's Orange Pippin' apple tissue samples in the range of 0 to $-2 \mathrm{MPa}$ was experimentally determined and shown in Fig. 3; $a$ and $b$ were calculated by fitting Eq. (13) to these data; $a$ had a value of $45.25 \mathrm{MPa}$ and $b$ a value of $40.72 \mathrm{MPa}$.

The relative humidity in the storage rooms was $95 \% \mathrm{RH}$, the temperature $3^{\circ} \mathrm{C}$.

A total of 12 parameters $\left(k_{\mathrm{S}}, k_{\mathrm{H}}, k_{\mathrm{l}}, h_{\mathrm{s}}, h_{\mathrm{a}}, c, d\right.$, $e, F_{\max , \mathrm{L}}^{\mathrm{t}}, E_{0}, f$ and $g$ ) remain to be estimated by fitting the model solution to the experimental data. The model was fitted by means of a software package developed by Verlinden et al. (1996). Only five parameters were allowed to change for the two storage conditions, namely $k_{\mathrm{S}}, k_{\mathrm{H}}, k_{\mathrm{L}}, h_{\mathrm{s}}$ and $h_{\mathrm{a}}$. The reason behind this was that the three rate constants may be affected by the air composition in the cool rooms; the two transfer coefficients might also be different for the two storage conditions because they were stored in cool rooms of different design, and hence air flow pattern and velocity. 
The integration of the differential equations was done with a variable order, variable step Gearmethod (NAG integration routine D02EBF). Parameters were fitted with a least squares procedure (NAG minimisation routine E04FDF). The NAG routine E04YCF was used to calculate the variance-covariance matrix from which the correlation matrix of the estimated model parameters and their standard deviation was calculated.

\section{Results and discussion}

Table 3 lists the estimated values of the fitted model parameters. The correlation matrix of these model parameters was calculated and is listed in Table 4 . It was clear that the correlation between all model parameters was relatively low which indicated that the model was not over-parameterised. The only exceptions were $g$ and $E_{0}$ which had a correlation coefficient of -0.96 . It is not clear from the model structure why this was the case.

Table 3

Model parameter values with $95 \%$ confidence interval estimated by fitting

\begin{tabular}{|c|c|c|}
\hline \multirow{2}{*}{$\begin{array}{l}\text { Model } \\
\text { parameter }\end{array}$} & \multicolumn{2}{|c|}{ Estimate $\pm 95 \%$ confidence interval } \\
\hline & $\begin{array}{l}\text { Ait storage } \\
\text { conditions }\end{array}$ & $\begin{array}{l}\text { CA storage } \\
\text { conditions }\end{array}$ \\
\hline$k_{\mathrm{S}}(1 / s)$ & $\begin{array}{l}(0.757 \pm 0.153) \\
\times 10^{-6}\end{array}$ & $\begin{array}{l}(0.543 \pm 0.542) \\
\times 10^{-6}\end{array}$ \\
\hline$k_{\mathrm{H}}(1 / \mathrm{s})$ & $\begin{array}{l}(0.0265 \pm 131) \\
\times 10^{-12}\end{array}$ & $\begin{aligned} &(4.20 \pm 30400000) \\
& \times 10^{-18}\end{aligned}$ \\
\hline$k_{\mathbf{L}}(1 / s)$ & $\begin{array}{l}(0.0702 \pm 0.0134) \\
\times 10^{-6}\end{array}$ & $\begin{array}{l}(0.0260 \pm 0.00682) \\
\times 10^{-6}\end{array}$ \\
\hline$h_{\mathrm{a}}\left(\mathrm{mol} / \mathrm{m}^{2}\right.$. Pa.s $)$ & $\begin{aligned} &(1.08 \pm 0.157) \\
& \times 10^{-12}\end{aligned}$ & $\begin{array}{l}(0.628 \pm 0.108) \\
\times 10^{-12}\end{array}$ \\
\hline$h_{\mathrm{s}}\left(\mathrm{mol} / \mathrm{m}^{2} \cdot \mathrm{Pa} . \mathrm{s}\right)$ & $\begin{aligned} &(34.5 \pm 21.0) \\
& \times 10^{-15}\end{aligned}$ & $\begin{array}{l}(0.231 \pm 2.51) \\
\times 10^{-15}\end{array}$ \\
\hline$c\left(\mathrm{~mm}^{2} \mathrm{~kg} / \mathrm{mol}\right)$ & \multicolumn{2}{|c|}{$20.6 \pm 0.946$} \\
\hline$d(\mathrm{~N})$ & \multicolumn{2}{|c|}{$13.2 \pm 2.19$} \\
\hline$e\left(\mathrm{~m}^{2}\right)$ & \multicolumn{2}{|c|}{$(18.7 \pm 4.98) \times 10^{-6}$} \\
\hline$F_{\max . L}^{\mathrm{t}}(\mathrm{N})$ & \multirow{2}{*}{\multicolumn{2}{|c|}{$\begin{array}{l}0.885 \pm 3.10 \\
(1.84 \pm 0.566) \times 10^{6}\end{array}$}} \\
\hline$E_{0}(\mathrm{~Pa})$ & & \\
\hline$g(\mathrm{~Pa} / \mathrm{mol})$ & \multicolumn{2}{|c|}{$\begin{array}{l}0.895 \pm 0.758 \\
(97.9+30.3) \times 10^{6}\end{array}$} \\
\hline
\end{tabular}

The rate constants for the degradation reactions of starch, sugar and middle lamella were higher for apples stored in normal air composition compared with apples stored in CA conditions. This seems reasonable as the latter are known to have a retarding effect on respiratory activity. Also the mass transfer coefficient from the symplast to the apoplast was higher for the apples stored in normal air conditions.

The difference in mass transfer coefficients from the apoplast to the environment between the two storage conditions may be caused by the fact that because of experimental restrictions two cool rooms of different design were used. This implies that the air flow pattern and velocity field inside the rooms might be different as well which in turn might affect the mass transfer coefficients considerably. Also, the accuracy of the hygrometers may be different in the two cool rooms.

The confidence interval of the estimate of $k_{\mathrm{H}}$ was for both storage conditions extremely large and included zero. This means that there was not enough information in the experimental data to estimate this parameter. This was also the case for $h_{s}$ for the CA-stored apples. Likewise, $F_{\max , \mathrm{L}}$ was not significantly different from zero. This indicated that the tissue tensile strength does seem to depend on the cell wall strength only. In other words, the cell wall always seems to be weaker than the middle lamella, if present.

In Fig. 4, the experimental data of the five output variables were plotted against storage time together with the simulated model values. The symbols were the averages of 20 measurements. The $95 \%$ confidence interval of the mean was given by vertical bars. By examining the figure it can be seen that the model fitted the data very well, although the model slightly underestimated the tensile strength (crispiness) in the case of apples stored in air (Fig. 4e). Juiciness and hardness were estimated more adequately (Fig. $4 \mathrm{c}$ and a). According to the model, the soluble solids for the apples stored in normal air composition kept on increasing after 100 days while apples stored in CA conditions reached a more or less constant value (Fig. 4a). This could not be verified by experimental measurements because the measuring technique did not allow the juice to be sam- 


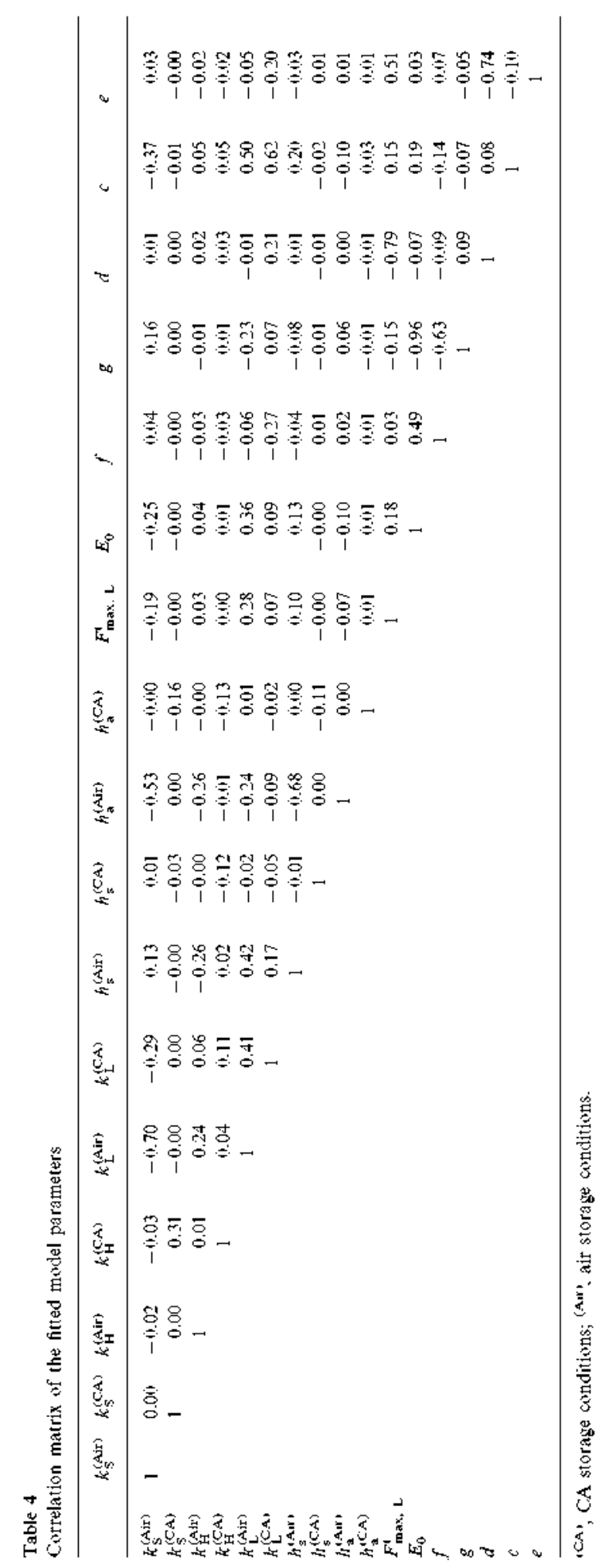




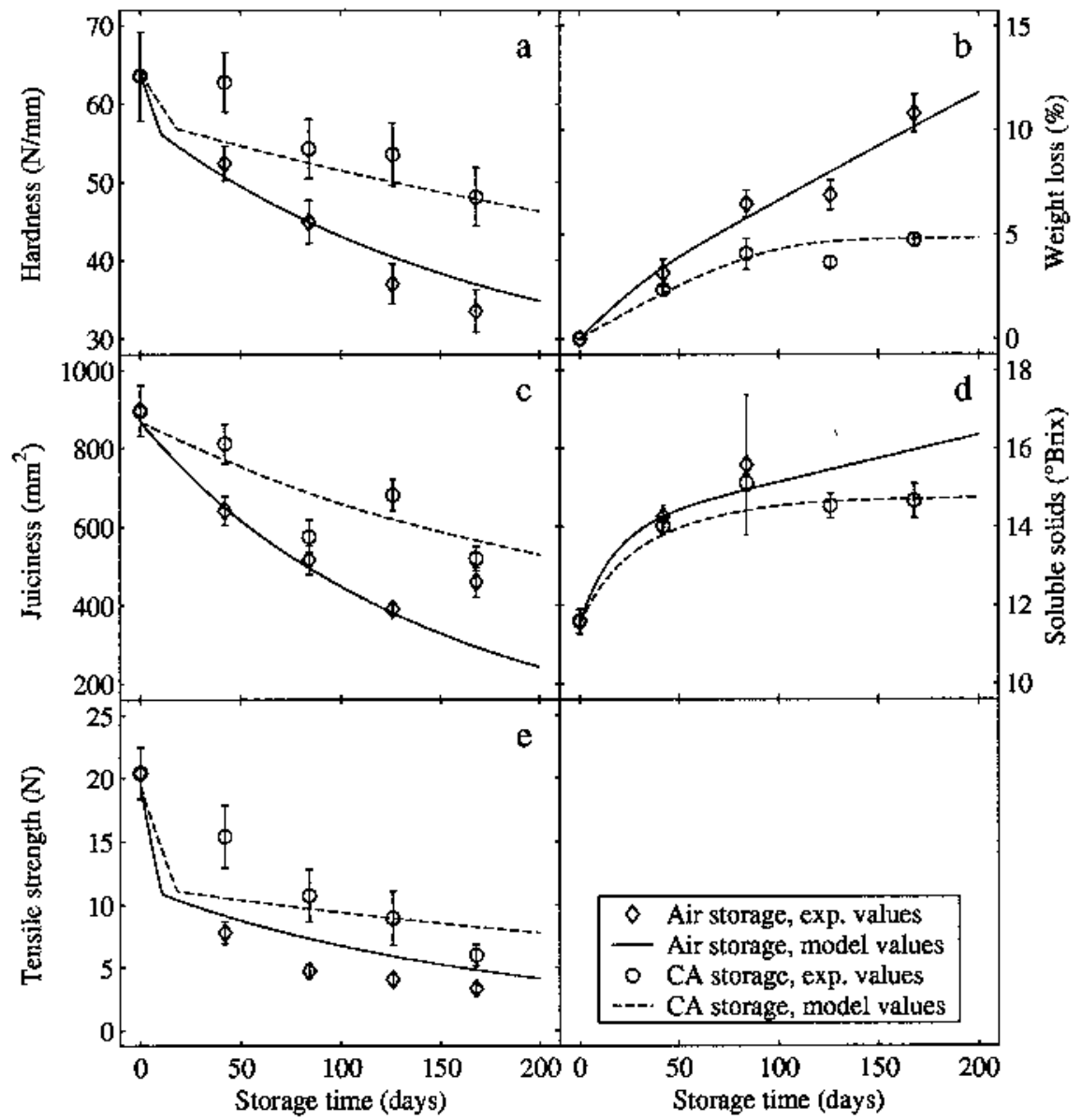

Fig. 4. Change of the measured output variables during storage. Error bars denote $95 \%$ confidence intervals of the mean of 20 measurements (note, the value of soluble solids after 84 days of air storage is the mean of only three measurements).

pled any more once the apples became rather mealy, for the normal air storage condition. However, this prediction was plausible because of the concentration effect one can expect from of the considerable weight loss (Fig. 4b). The model fitted the weight loss well.

Fig. 5 shows the apple behaviour during storage. During the first 50 days of storage, starch was degraded (Fig. 5a) in favour of hexose and the concentration of the latter increased correspondingly in this period (Fig. 5b). Degradation and production were faster in normal air than in CA storage conditions. After about 100 days all starch was gone and the concentration of hexose decreased. However, this consumption of hexose was very limited and almost not noticeable because respiration rates of fruit stored in these conditions was very low. The pectin in the middle lamellae was degraded gradually during the whole storage period (Fig. 5c) but with a far higher rate in normal air conditions, resulting in less middle lamellae and more solubilised pectin at the end of the storage period compared with $\mathrm{CA}$ storage (Fig. 5d). Fig. 5e and $f$ show the water state in the apple. In the case of CA-stored apples a considerable decrease in apoplastic water content was observed, while the symplastic water content remained almost constant throughout the whole storage period. In the normal air-stored apples, a considerable amount of symplastic water was lost 
through the apoplast to ambient and this explained the large weight loss of the apples. Note that the apoplastic water content represented a dynamic equilibrium between water influx from the symplast and water loss to ambient. The mass transfer coefficients from the apoplast to ambient was for both $\mathrm{CA}$ and air conditions, much smaller than that from the symplast to the apoplast, which confirmed that the skin was the major barrier with respect to moisture transport. The large difference in symplastic to apoplastic mass transfer coefficient between $\mathrm{CA}$ and air storage might be due to the fact that in the latter case the tissue was more mealy, and hence the cells were more rounded and detached from each other (De Smedt et al., 1998). The surface area available for water exchange to the apoplast was in this case considerably larger.
Fig. 6 shows four intermediate variables that are functions of the state and which determine the output variables of the model. Fig. 6a shows the osmotic potential in the symplast which was closely related to the water concentration (see Fig. 5e). Fig. 6b, shows the water potential in the apoplast. The water potential decreased corresponding with a reduction in water concentration, and levelled off after about 150 days of storage. This level was lower in CA conditions despite a lower mass transfer rate from apoplast to ambient. The change in turgor pressure is shown in Fig. 6c. Because of the high water loss, accounting for most of the weight loss, turgor pressure was already lost after 12 and 20 days in normal air and CA storage, respectively. The turgor pressure was responsible for the sudden drop in tensile

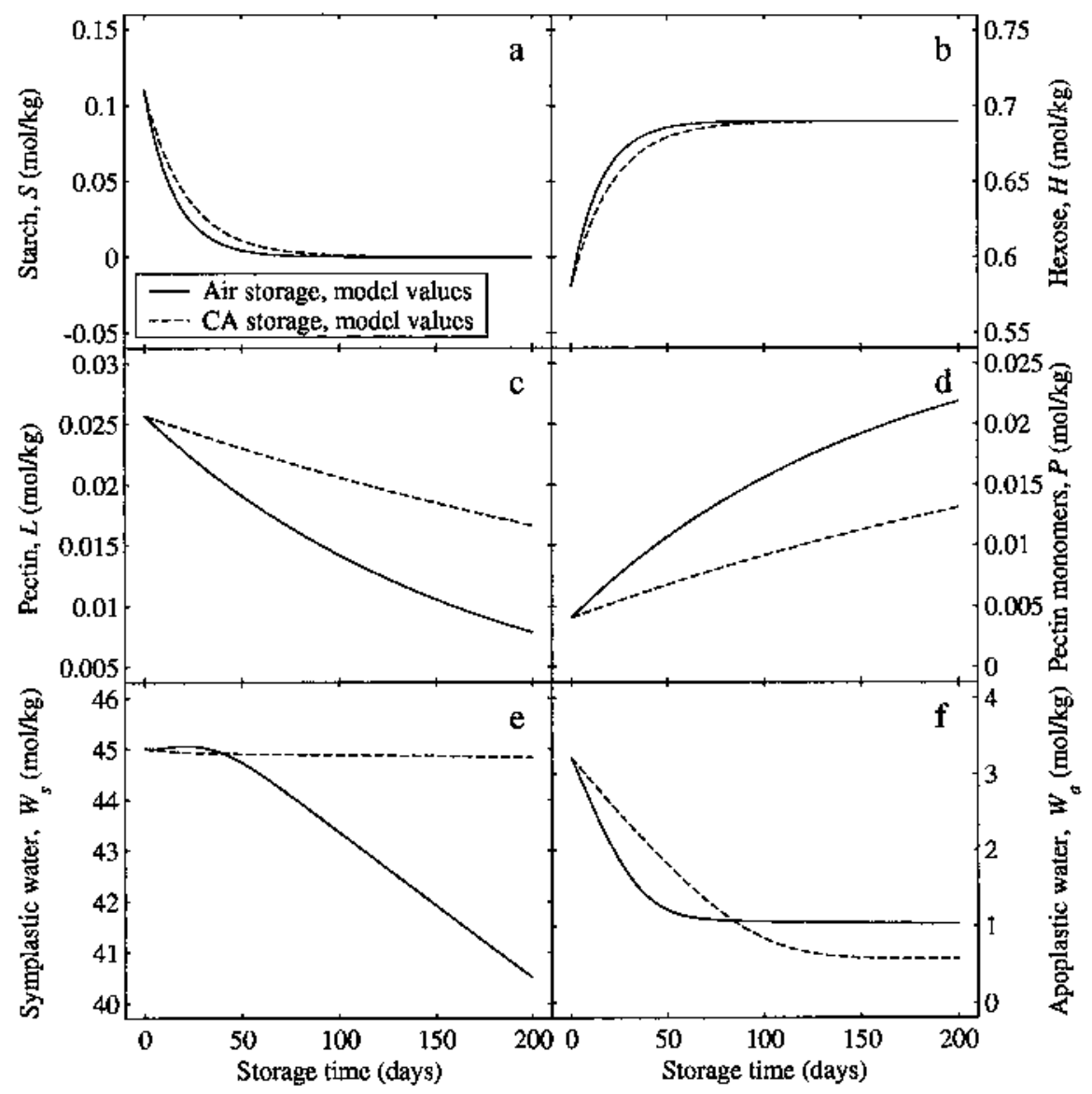

Fig. 5. Change of the state variables during storage. 


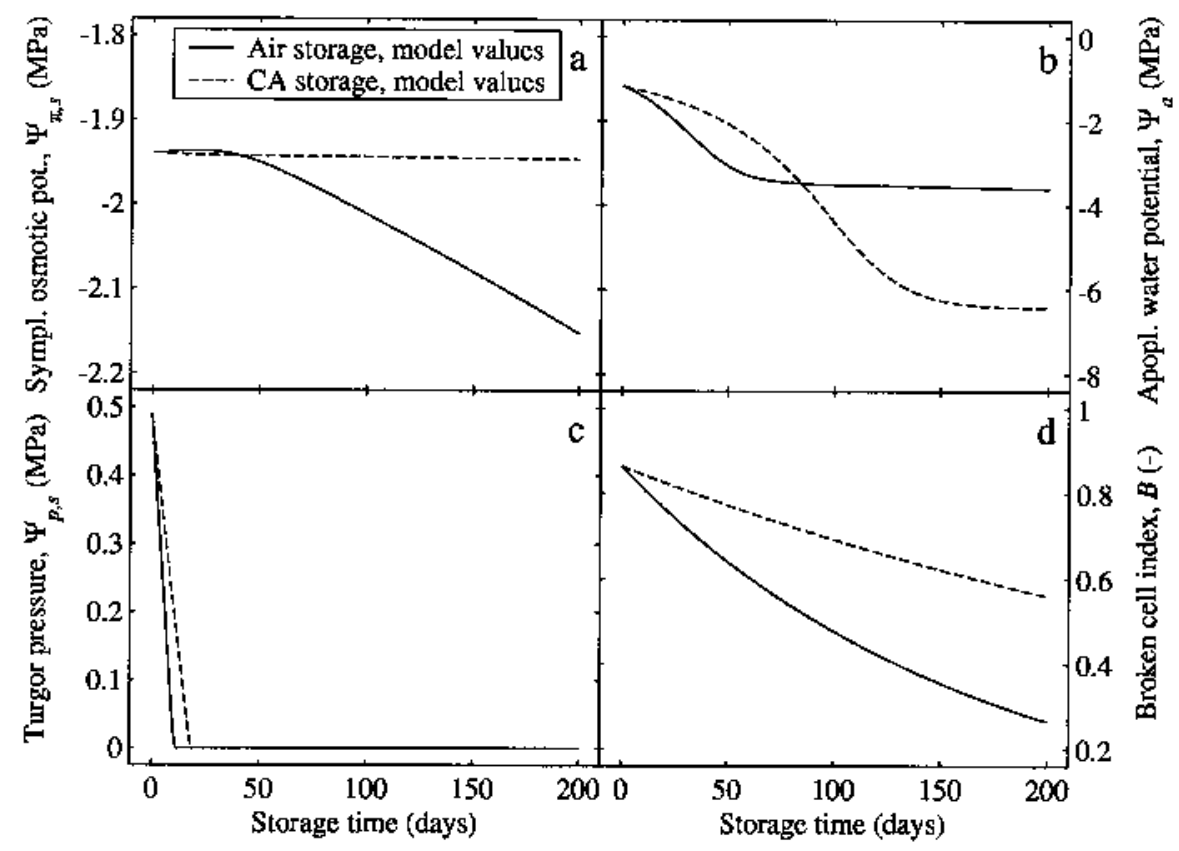

Fig. 6. Change of some important intermediate variables during storage.

strength and to a lesser extent in hardness during normal air storage. Whereas, in CA storage the symplastic water concentration seemed to be constant, there was a clear loss of symplastic water under air storage (Fig. 5e). Although this seemed to indicate complete plasmolysis, this was not necessarily true as the apple has been considered as a bulked object in this article. Most probably the loss of symplastic water occurred just beneath the skin where complete turgor loss and even plasmolysis may be expected, whereas the rest of the apple was still turgid. A refinement of this model which would include spatial effects such as water diffusion in the tissue might elucidate this further. Fig. $6 \mathrm{~d}$ shows the change of the broken cell index which was mainly responsible for the change in juiciness.

Sensory experiments which were carried out simultaneously with the instrumental measurements described in this article (De Smedt, 2000), showed that the apples stored in normal air composition were more mealy than those stored in CA. According to the model this could be explained through an accelerated degradation of starch and a more pronounced dissolution of the middle lamella.

Fig. 7 shows the effect of relative humidity on the output variables of the model by three model simulations in which the relative humidity was set to 90,95 and $98 \%$. It is clearly seen from Fig. $7 \mathrm{~b}$, that juiciness was not sensitive to changes in relative humidity. This was in accordance with the common knowledge that a wrinkled apple that has experienced considerable water loss, can still be juicy. The largest effect was observed with respect to tensile strength (Fig. $7 \mathrm{c}$ ) and hardness (Fig. 7a) which increased with increasing relative humidity, mainly due to the fact that turgor pressure was maintained at non-zero for a longer period. Obviously weight loss was sensitive to relative humidity as well (Fig. $7 \mathrm{~d}$ ). A lower relative humidity resulted in a higher weight loss. This was most pronounced in normal air storage.

To illustrate that the high weight loss observed in the experiment with normal air conditions might be due, at least partly, to high air velocities and so to a high mass transfer coefficient because 
of the different cool rooms which were used because of practical constraints, a simulation was carried out in which $h_{\mathrm{a}}$ for normal air storage conditions was set to the same value as the one for CA storage. The results are shown in Fig. 8. Clearly the effects on hardness, juiciness and crispiness were marginal (Fig. 8a, c and e). However, the weight loss (Fig. 8b) was much lower than the one which was actually observed, and coincides during the first 100 days with the weight loss observed in CA conditions. This resulted in a much more reasonable weight loss at the end of the storage period. Since less water was lost, the soluble solids concentration was smaller which resulted in lower SSC values (Fig. 8d). The weight loss under $\mathrm{CA}$ at $90 \% \mathrm{RH}$ was about $6 \%$ and smaller than expected from practical experience. This may be due to extrapolation of the model beyond its validity range or may indicate some defficiences of the model.

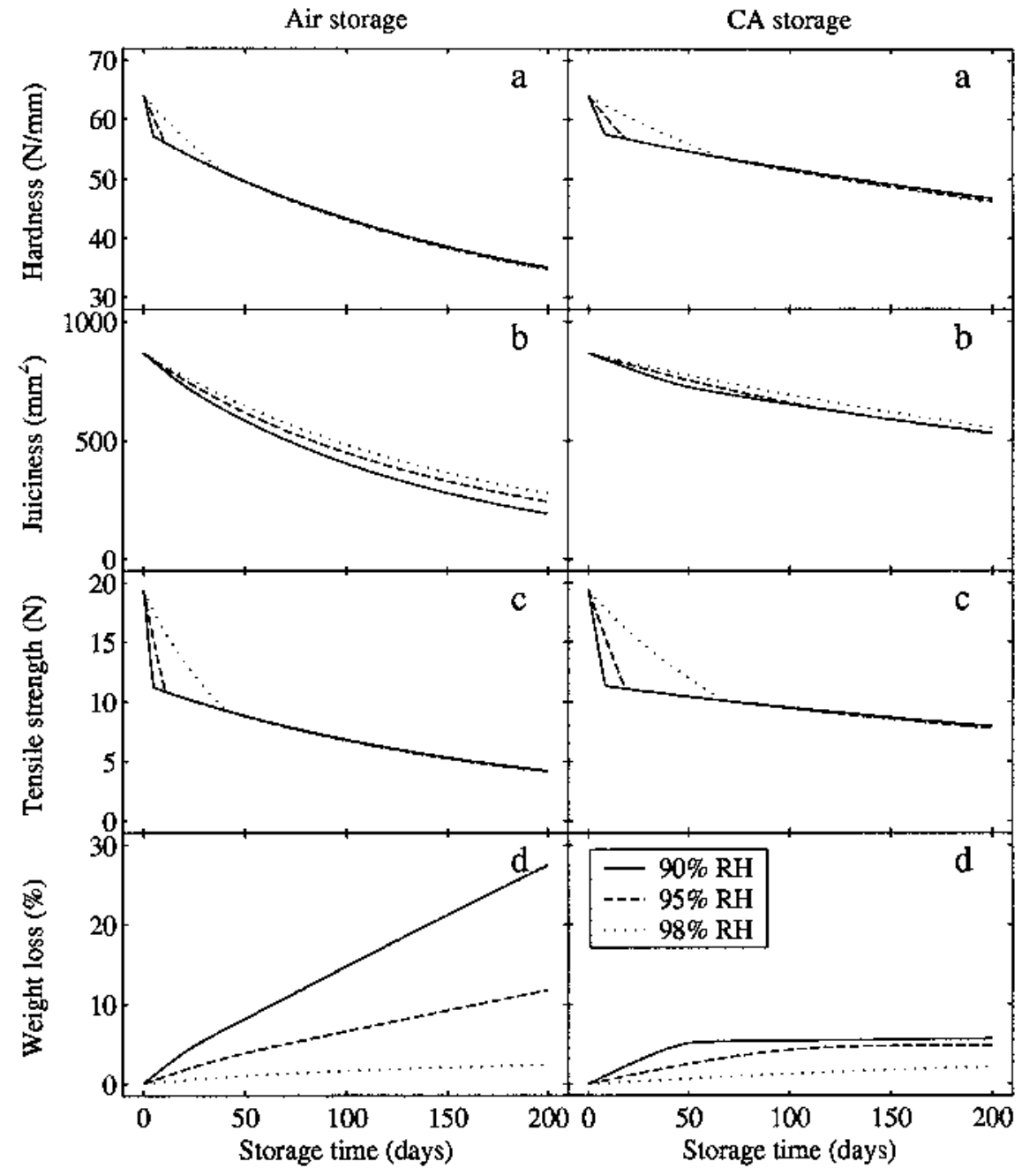

Fig. 7. Model simulation results to illustrate the effect of different relative humidity conditions on the change of four output variables during air and CA storage. 


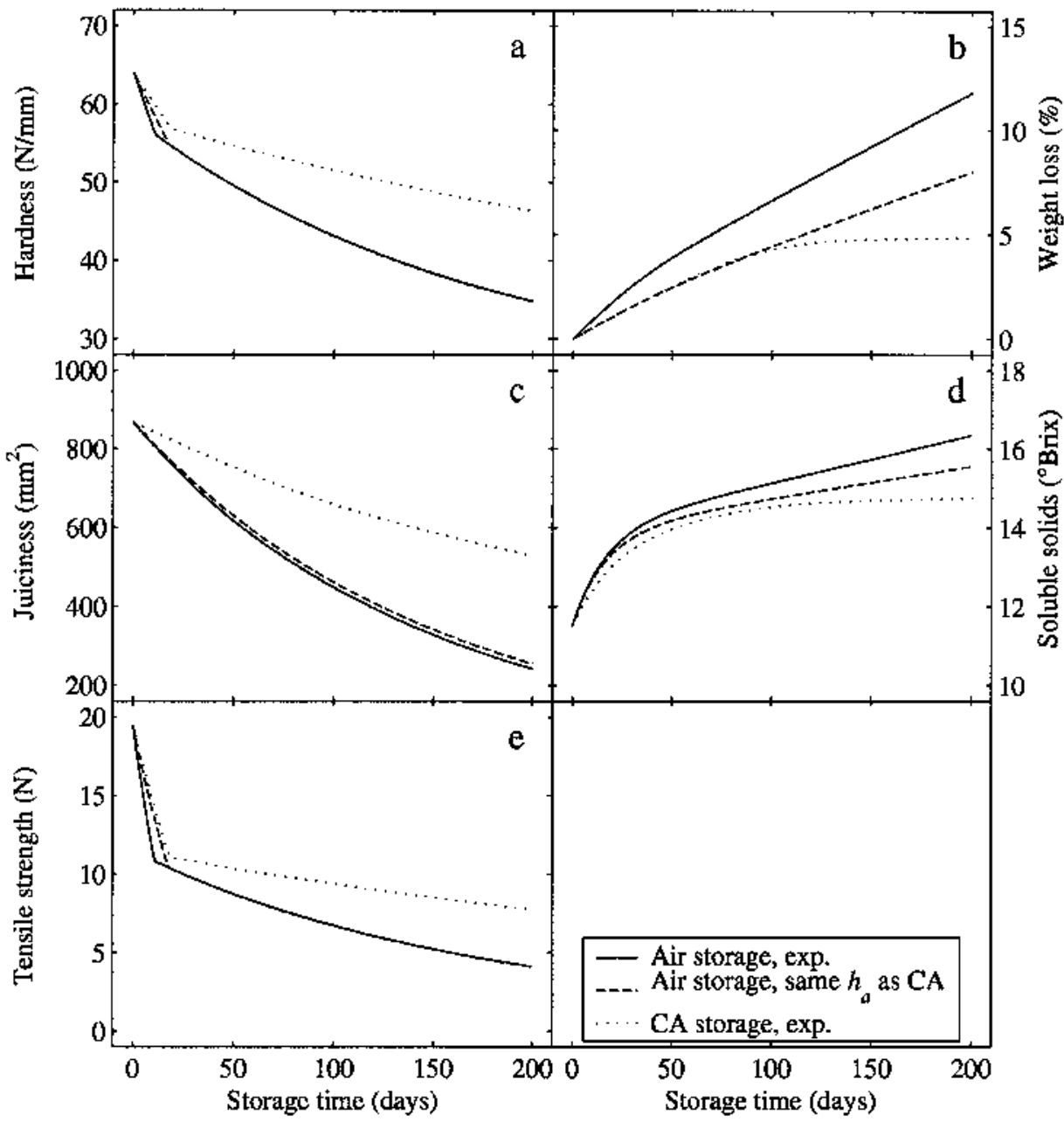

Fig. 8. Model simulation results to illustrate the effect of mass transfer coefficient of water transfer through the apple skin to the ambient.

\section{Conclusions}

The mathematical model which has been developed does describe the mealiness-related texture changes of apple during $\mathrm{CA}$ and air storage reasonably well. However, only a limited amount of experimental data were available to check the feasibility of the model. More experimental data would be needed to check all hypotheses made during the construction of the model. Furthermore, it would also be useful to include detailed measurements of the state variables of the model, such as the apoplastic and symplastic water, the turgor pressure and the pectin content. Also, a validation of the model using an independent data set is mandatory.

The model is built by assuming that the temperature is constant and optimal for the storage of apples. When apples are stored under temperature conditions which are higher than optimal, the development of mealiness will be accelerated. This would influence the parameters of the system, notably the rate constants and the water potentials. As the oxygen concentration is constant during the storage period except at the start of the storage, it can readily be assumed that different 
oxygen concentrations only influence the respiration rate constant. A more complete model in which these dependencies are explicitly modelled would allow us to predict and, hence, optimise the development of mealiness under arbitrary storage conditions.

\section{Notation}

$a$
$a_{\mathrm{w}}$
$A_{\mathrm{s}}$
$A_{\mathrm{s}}^{*}$
$A_{\mathrm{a}}$
$A_{\mathrm{a}}^{*}$
$A_{\mathrm{p}}$

Ash

$B$

$c$

$C_{n}$

$d$

$e$

E

$E_{0}$

$f$

$F_{\text {max }}$

$F_{\max , \text { wall }}^{\mathrm{t}}$

$F_{\max , \mathrm{L}}^{\mathrm{t}}$

$g$

$h_{s}$

$h_{\mathrm{a}}$

H

$H$

$J$

$k$

$l_{\mathrm{p}}$ coefficient Eq. (13) (Pa)

water activity $(-)$

specific cell membrane area $\left(\mathrm{m}^{2} / \mathrm{kg}\right)$

total cell membrane area $\left(\mathrm{m}^{2}\right)$

apple surface area $\left(\mathrm{m}^{2}\right)$

cross section of the probe used for

the confined compression test $\left(\mathrm{m}^{2}\right)$

proportion of ash of the apple

fresh weight $(-)$

coefficient (Eq. (13)) (Pa)

broken cell index $(-)$

coefficient Eq. (34) $\left(\mathrm{mm}^{2} \mathrm{~kg} / \mathrm{mol}\right)$

mannitol concentration $\left(\mathrm{mol} / \mathrm{m}^{3}\right)$

coefficient $\mathrm{Eq}$. (36) (N)

coefficient $\mathrm{Eq}$. (36) $\left(\mathrm{m}^{2}\right)$

elasticity modulus of the apple

flesh $(\mathrm{Pa})$

coefficient Eq. (37) (Pa)

coefficient $\mathrm{Eq}$. (37) (-)

tensile strength $(\mathrm{N})$

tensile strength of the cell wall (N)

tensile strength of the middle

lamella $(\mathrm{N})$

coefficient Eq. (37) $(\mathrm{Pa} / \mathrm{mol})$

mass transfer coefficient of water

transfer from the symplast to the apoplast $\left(\mathrm{mol} / \mathrm{m}^{2} \mathrm{~Pa} \mathrm{~s}\right.$ )

mass transfer coefficient of water

transfer from the apoplast to the

ambient ( $\mathrm{mol} / \mathrm{m}^{2} \mathrm{~Pa} \mathrm{~s}$ )

hexose unit

moles of hexose per $\mathrm{kg}$ fresh

weight of apple tissue $(\mathrm{mol} / \mathrm{kg}$ )

juiciness $\left(\mathrm{mm}^{2}\right)$

rate constant $(1 / \mathrm{s})$

length of the probe used for the

confined compression test (mm) specific apple surface area $\left(\mathrm{m}^{2} / \mathrm{kg}\right)$
L dissolution site on the pectin chains of the middle lamellae

$L \quad$ moles of dissolution sites of the middle lamella per $\mathrm{kg}$ fresh weight apple tissue $(\mathrm{mol} / \mathrm{kg})$

$m_{\text {apple }} \quad$ mass of the apple $(\mathrm{kg})$

$\Delta m$

$\mathrm{M}$

weight loss of the apple $(\%)$

$M$

Mannitol

$n$

$\mathrm{P}$

$P$

molecular mass $(\mathrm{g} / \mathrm{mol})$

number of moles (mol)

pectin monomer

moles of pectin monomers per $\mathrm{kg}$

fresh weight of apple tissue (mol/

$\mathrm{kg}$ )

$r \quad$ flow rate $(\mathrm{mol} / \mathrm{s})$

$R \quad$ universal gas constant, $8.3143(\mathrm{~J} /$

mol K)

S dissolution site on starch chains

$S \quad$ moles of dissolution sites on starch

per $\mathrm{kg}$ fresh weight of apple tissue

(mol $/ \mathrm{kg})$

$S_{c c} \quad$ hardness $(\mathrm{N} / \mathrm{mm})$

SSC Percentage of soluble solids in the juice $\left[{ }^{\circ} \mathrm{Brix}\right]$

$t$ Time (s)

$T \quad$ Temperature $(\mathbf{K})$

$v \quad$ Reaction rate $(1 / \mathrm{s})$

$\bar{V} \quad$ Molar volume $\left(\mathrm{m}^{3} / \mathrm{mol}\right)$

W Water molecule

$W \quad$ Moles of water per kg fresh weight of apple tissue $(\mathrm{mol} / \mathrm{kg})$

Greek symbols

$\begin{array}{ll}\delta & \text { activity coefficient }(-) \\ \varepsilon & \text { parameter }(-) \\ \phi_{\text {rel }} & \text { relative humidity }(-) \\ v & \text { Poisson's ratio } \\ \Psi & \text { total water potential }(\mathrm{Pa}) \\ \Psi_{\mathrm{p}} & \text { turgor potential }(\mathrm{Pa}) \\ \Psi_{\pi} & \text { osmotic potential }(\mathrm{Pa}) \\ {[]} & \text { mole fraction }\end{array}$

\section{Subscripts}

$0 \quad$ initial condition

H Hexose unit

L middle lamella

$\mathrm{P} \quad$ pectin monomer 


$\begin{array}{ll}\text { S } & \text { symplast } \\ \text { S } & \text { starch } \\ \text { W } & \text { water } \\ \text { A } & \text { apoplast } \\ \infty & \text { ambient }\end{array}$

\section{Acknowledgements}

The financial support from the E.U. (FAIR project CT95-0302) and the Flemish Ministry for Science and Technology is gratefully acknowledged. Author Els Veraverbeke is a doctoral fellow of the IWT. We would like to thank the reviewers for their exceptionally lucid contribution which led to some substantial improvement of the model.

\section{References}

Barreiro, P., Ortiz, C., Ruiz-Altisent, M., Recasens, I., Asensio, M.A., 1998a. Mealiness in apples. Comparison between human and instrumental procedures and results. Procedings of SENSORAL98: From Sensors to Decision Support in Agriculture, Food Industry and Enviroment. vol. 2, pp. 245-257. CEMAGREF, Montpellier, France. ISBN 2-85362-499-4.

Barreiro, P* Ottiz, C. Ruiz-Altisent, M., De Smedt, V., Schotte, S., Andani, Z., Wakeling. I., Beyts, P.K., 1998b. Comparison between sensory and instrumental measurements for mealiness assessment in apples: a collatorative experiment. J. Texture Stud. 29, 509-525.

Barreiro, P., Ortiz, C.. Ruiz-Altisent, M., Ruiz-Cabello, J.. Fernández-Valle, M.E., Recasens, I., Asensio, M., 2000. Mealiness assessment in apples and peaches using MRI techniques. Magn. Reson. Imaging 18, 1175-1181.

Belitz, H.D., Grosch, W., 1997. Food Chemistry. Springer, Berlin.

Ben-Arie, R., Kislev, N, 1979. Ultrasttuctural changes in the cell walls of ripening apple and pear truit. Plant Physiol. 64, 197-202.

De Bacrdemaeker, J., Segerlind, L.J., 1976. Determination of the viscoelastic properties of apple flesh. Trans. ASAE 19, $346-349$.

De Baerdemaeker, J., Segerlind, L.J., Murase, J., Merva, G.E..
1978. Water potential effect on tensile and compressive failure stresses of apple and potato tissue. ASAE paper no. 78-3057. American Society of Agricultural Engineers, St. Joseph, MI.

De Smedt, $V_{*}, 2000$. Measurement and modelling of mealiness in apples. Ph.D. thesis, Katholieke Universiteit Leuven, Leuven, Belgium.

De Smedt, V., Pauwel, E., De Baerdemaeker, J., Nicolaü, B., 1998. Microscopic observation of mealiness in apples: a quantitative approach. Postharvest Biol. Technol. 14, 151158.

Fisher, R.L., Benoet, A.B., 1991. Role of hydrolases in fruit tipeniog. Anuu. Rev. Plant Physiol. Plant Mol. Biol. 42, $675-703$.

Harker, F.R., Hallett, I.C.. 1992. Physiological changes associated with development of mealiness of apple fruit during cool storage. Hortscience 27, 1291-1294.

Hatfield, S.G.S., Knee, M., 1988. Effects of water loss on apples during stotage. Int. J. Food Sci. Technol. 23, 575583.

Herrero, A., Guardia, J., 1992. Conservación de frutos. Manual técnico. Ediciones Mundi-Prensa, Madrid, Spain.

Hertog, M.L.A.T.M., Tijskens, L.M.M. Hak, P.S., 1997. The eftects of temperature and senescence on the accumulation of reducing sugars during storage of potato tubers: a mathematical model. Postharvest Biol. Technol. 10, 67-79.

Kays, S.J., 1991. Postharvest Physiology of Perishable Plant Products. Van Nostrand Reinhold, New York.

Nilsson, S.B. Hertz, C.H., Falk, S. 1958. On the relation between turgor pressure and turgor rigidity. II. Theoretical calculations on model systems. Physiol. Plant 11, 818-837.

Nobel. P.S., 1991. Physicochemical and Environmental Plant Physiology. Academic Press, New York.

Pitt, R.E., 1982. Models for the rheology and statistical strength of uniformly stressed vegetative tissue. Trans. ASAE 25 (6), 1776-1784.

Reeve, R.M., 1953. Histological investigations of texture in apples. II structure and apoplast. Food Res. 18, 604-615.

Taiz, L.. Zeiger, E., 1998. Plant Physiology, second ed. Sinauer Associates, Sunderland, MA.

Vau Buren, J.P. 1979. The chemistry of texture in fruits and vegetables. J. Texture Stud. 10, 1-23.

Vetlinden, B.E., De Baetdemaeker, J., 1997. Modelling low temperature blanched carrot firmness based on heat induced processes and enzyme activity. J. Food Sci. 62 (2). $1-6$.

Vetlinden, B. De Barsy, T. De Baetdemaeker, J. Deltour, R., 1996. Modelling the mechanical and histological properties of cartot tissue during cooking in relation to texture and cell wall changes. J. Texture Stud. 27, 15-28. 